\title{
Author Correction: The CaMKII/NMDA receptor complex controls hippocampal synaptic transmission by kinase-dependent and independent mechanisms
}

\author{
Salvatore Incontroํ, Javier Díaz-Alonso ${ }^{1}$, Jillian lafrati ${ }^{2}$, Marta Vieira ${ }^{3}$, Cedric S. Asensio (i) ${ }^{4}$, Vikaas S. Sohal ${ }^{2}$, \\ Katherine W. Roche ${ }^{3}$, Kevin J. Bender ${ }^{5}$ \& Roger A. Nicoll ${ }^{1,6}$
}

Correction to: Nature Communications; https://doi.org/10.1038/s41467-018-04439-7; published online 25 May 2018

The originally published version of this article contained errors in Fig. 5, for which we apologise. In panel c, the scatter graph was inadvertently replaced with a scatter graph comprising a subset of data points from panel d. Furthermore, the legends to Fig. $5 \mathrm{c}$ and $\mathrm{d}$ were inverted. These errors have now been corrected in both the PDF and HTML versions of the article, and the incorrect version of Fig. $5 \mathrm{c}$ is presented in the Author Correction associated with this Article.

Published online: 03 December 2018

Open Access This article is licensed under a Creative Commons Attribution 4.0 International License, which permits use, sharing, adaptation, distribution and reproduction in any medium or format, as long as you give appropriate credit to the original author(s) and the source, provide a link to the Creative Commons license, and indicate if changes were made. The images or other third party material in this article are included in the article's Creative Commons license, unless indicated otherwise in a credit line to the material. If material is not included in the article's Creative Commons license and your intended use is not permitted by statutory regulation or exceeds the permitted use, you will need to obtain permission directly from the copyright holder. To view a copy of this license, visit http://creativecommons.org/licenses/by/4.0/.
}

(c) The Author(s) 2018

\footnotetext{
${ }^{1}$ Department of Cellular and Molecular Pharmacology, University of California, San Francisco, San Francisco, CA 94158, USA. ${ }^{2}$ Department of Psychiatry, University of California, San Francisco, San Francisco, CA 94158, USA. ${ }^{3}$ Receptor Biology Section, National Institute of Neurological Disorders and Stroke, National Institutes of Health, Bethesda, MD 20892, USA. ${ }^{4}$ Department of Biological Sciences, University of Denver, Denver, CO 80208, USA. ${ }^{5}$ Department of Neurology, University of California, San Francisco, San Francisco, CA 94158, USA. ${ }^{6}$ Department of Physiology, University of California, San Francisco, San Francisco, CA 94158, USA. Correspondence and requests for materials should be addressed to S.I. (email: salvincontro@gmail.com)

or to R.A.N. (email: roger.nicoll@ucsf.edu)
} 
a

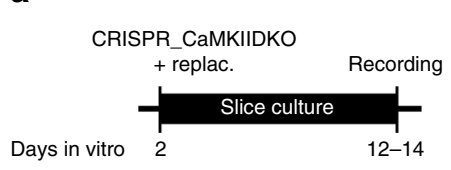

b

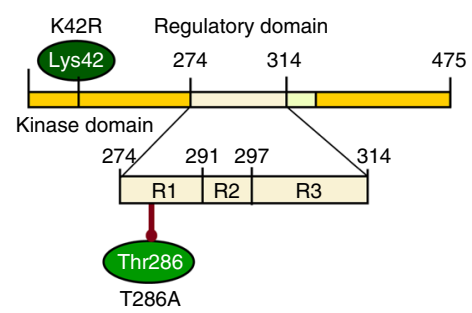

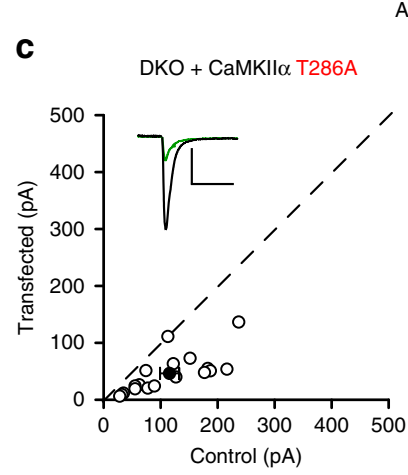

AMPAR EPSCs

d
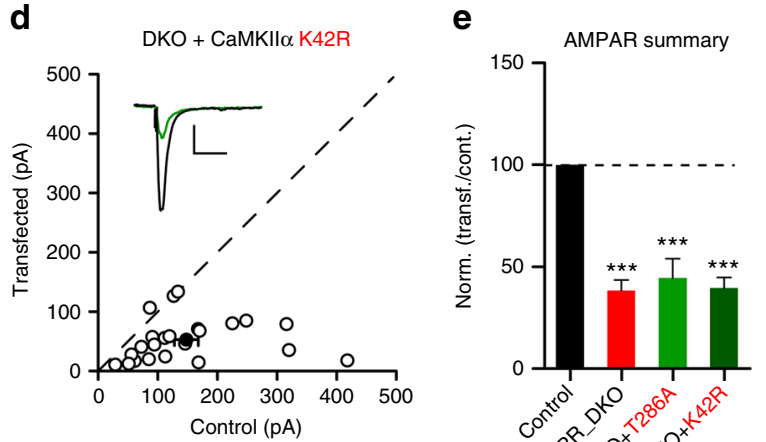

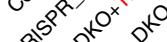



NMDAR EPSCS

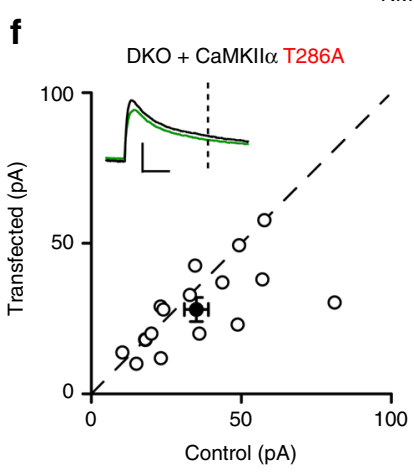

g
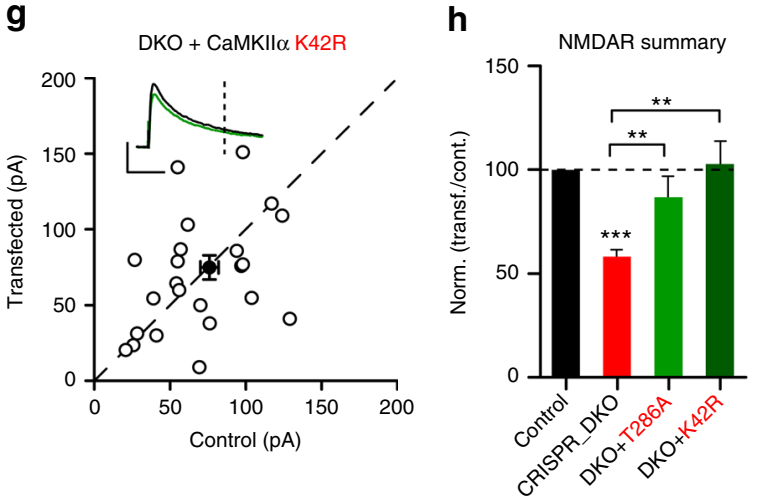

i

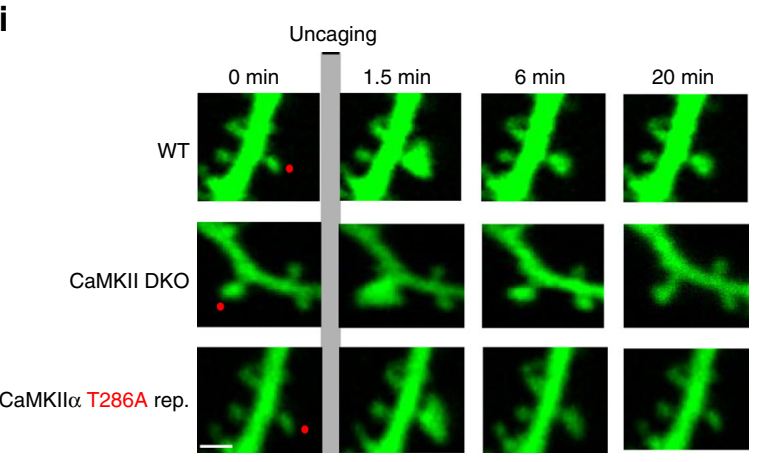

j

k

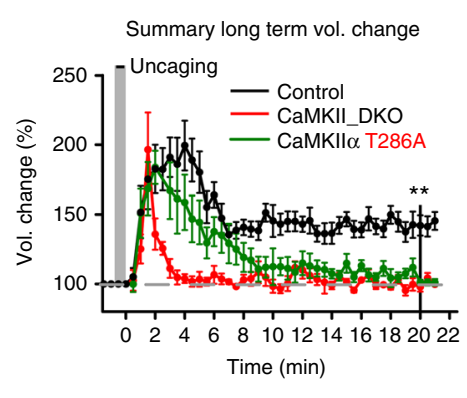

Vol.ch. @ 20 mins

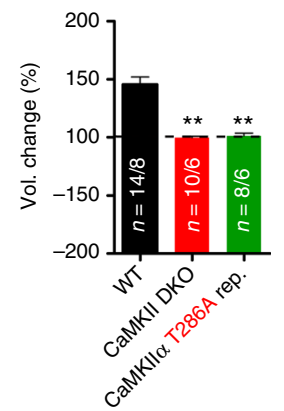

Fig. 1 